\title{
Prevalence of Hypertensive Retinopathy Changes in Pregnancy induced Hypertension
}

Anil kumar Bhupally ${ }^{1}$, Sindu Sulekha ${ }^{1}$, Rama Devi ${ }^{2}$, Swathi M $* 3$, Rohini M ${ }^{4}$ Shruthi $T^{5}$,

${ }^{1}$ Associate Professor, Department of Ophthalmology, Chalmeda Anand Rao Institute of Medical Sciences, Karimnagar, Telangana, India.

2 Professor and HOD Department of Obstetrics and Gynaecology, Chalmeda Anand Rao Institute of Medical Sciences, Karimnagar, Telangana, India.

3,4,5 Post graduate students, Department of Ophthalmology, Chalmeda Anand Rao Institute of M edical Sciences, Karimnagar, Telangana, India.

\section{ABSTRACT}

Aim: To determine the prevalence of retinal changes in pregnancy-induced hypertension (PIH) and to determine any association between retinal changes and blood pressure (BP), proteinuria, blood urea, serum creatinine and severity of the disease.

Materials and M ethods: Patients admitted and diagnosed with PIH are included in the study over a period of 3 years. Age, gravida, gestational age, blood pressure, proteinuria, blood urea, serum creatinine were noted from the case records. History for any eye disease was taken, fundus examination done after dilating the eyes with $1 \%$ tropicamide, in a semi dark room in the ward

Results: A time period of 3 years from (June 2011 to June 2014) was taken and all the patients coming to OBG OPD with PIH were examined. Of 154 patients the mean age of patients were 23.68 $\pm 3.49 y$ year(range 18-38year). The gestational period ranged between $20-38$ weeks with mean $33.93 \pm 3.62$. Primigravida $85(56.7 \%), 47(32.1)$ $2^{\text {nd }}$ gravida, 22(13.01\%) were $3^{\text {rd }}$ gravida. $84(54.54 \%)$ Had mild preeclampsia, $61(39.61 \%)$ had severe preeclampsia, $9(5.84 \%)$ had eclampsia. Retinal changes were seen in $42(27.27 \%)$. There was statistically significant positive association of retinal changes and blood pressure $(p=0.0001)$, proteinuria $(p=0.0001)$, severity of the PIH $(p=0.0001)$ and no significant association found between retinal changes and blood urea( $p=0.507)$, serum creatinine $(p=0.614)$, serum $A / G(p=0.185)$.

Conclusion: Retinal changes were seen in $42(27.27 \%)$ of patients with PIH and they were significantly associated with blood pressure, proteinuria and severity of PIH.

KEY WORDS: Preeclampsia, Eclampsia, Retinal changes, Proteinuria.

Address for correspondence: Dr. Anil kumar Bhupally, MS (Ophthalmology), Associate Professor, Department of Ophthalmology, Chalmeda Anand Rao Institute of M edical Sciences, Bommakal, Karimnagar, Telangana 505001, India. E-M ail: dr_anil_b@yahoo.com

\begin{tabular}{|c|c|c|}
\hline \multicolumn{3}{|c|}{ Online Access and Article Informtaion } \\
\hline \multirow{2}{*}{$\begin{array}{c}\text { Quick Response code } \\
\text { Dol: 10.16965/ijims.2015.129 }\end{array}$} & \multicolumn{2}{|c|}{$\begin{array}{l}\text { International Journal of Integrative Medical Sciences } \\
\text { www.imedsciences.com }\end{array}$} \\
\hline & $\begin{array}{l}\text { Received: 13-10-2015 } \\
\text { Reviewed: } 14-10-2015\end{array}$ & $\begin{array}{l}\text { Accepted: 02-11-2015 } \\
\text { Published: 10-11-2015 }\end{array}$ \\
\hline Source of Funding: Self & & None \\
\hline
\end{tabular}

\section{INTRODUCTION}

Hypertension, according to American college of Obstetrics and Gynecology Committee task force, is defined as either a systolic pressure of $\geq 140 \mathrm{mmHg}$ or an increase of $\geq 30 \mathrm{mmHg}$ (from a base line in the first half of the pregnancy) or as a diastolic pressure of $\geq 90 \mathrm{mmHg}$ or an increase of $\geq 15 \mathrm{mmHg}$ from the base line [1]. Preeclampsia[PIH] is characterized by edema, proteinuria and hypertension. Significant proteinuria is defined as $>0.3 \mathrm{~g}$ protein per $24 \mathrm{hr}$ or $0.1 \mathrm{~g} / \mathrm{L}(>2+$ on the dipstick) in at least two 
random samples collected 60 minimum hours apart [1].

Hypertension is the most common medical disorder during pregnancy, affecting $6-8 \%$ of all pregnancies. $16-25 \%$ of $1^{\text {st }}$ pregnancy $\& 12-15 \%$ of subsequent pregnancies [2]. HTN during pregnancy can be classified into 4 categoriesChronic HTN, Gestational HTN, Preeclampsia, Eclampsia and superimposed preeclampsia [1]. Preeclampsia is gestational HTN $(140 / 90 \mathrm{mmHg}$ or a rise of $30 \mathrm{mmHg}$ of systolic pressure or a rise of $15 \mathrm{mmHg}$ of diastolic pressure taken on two occasions after rest, in combination with generalized edema or proteinuria of at least $300 \mathrm{mg} / 24 \mathrm{hr}$. Seizures or coma as a consequence of preeclampsia is termed as eclampsia [2]. PIH is multisystem disorder of unknown etiology. Preeclampsia is maternal response to placentation. The pathological changes of these diseases appear to be related to vascular endothelial dysfunction and its consequences. The retinal vascular changes generally but not always, correlate with severity of systemic HTN. Vasospastic manifestations are reversible and the retinal vessels rapidly returned to normal after delivery [3].

\section{MATERIALS AND METHODS}

This prospective cohort study, was conducted over a period of 36months (Jun 2011 to J un 2014). All the patients admitted to the obstetric ward CAIM S with diagnosis of PIH were included. Patients who had pre existing diabetes mellitus, HTN, cardiovascular disease, collagen vascular disease, renal disease and hazy media that did not permit fundus visualization were excluded from the study.

After taking history for any eye symptoms, anterior segment was examined with torch light on the bedside., to rule out any gross anterior segment pathology. Both the pupils were dilated with $1 \%$ tropicamide eye drops and ophthalmologist did fundus examination with direct ophthalmoscope in a semi dark room in ward. The retinal changes (HTN retinopathy) were graded according to Keith Wagner HTN retinopathy classification changes seen in right or left or both eyes and was taken as positive findings in that patient. Age, parity, gravida, BP, proteinuria, blood urea, serum creatinine, serum
$A / G$ were noted from case records and entered into data sheets and were analyzed through Openepi statistical software version 2.3. This study was approved by Ethical Committee, Chalmeda Anand Rao Institute of Medical Sciences, Karimnagar, India.

\section{RESULTS}

Out of 154 patients examined the mean age of patients was $23.68 \pm 3.49$ year(range 18-38yr). The gestational period ranged between 20-38 weeks with mean $33.93 \pm 3.62$. 85 primigravida (56.7\%) $47(32.1 \%) 2^{\text {nd }}$ gravida, $22(13.01 \%)$ were $3^{\text {rd }}$ gravida. 84 (54.54\%) mild preeclampsia, 61(39.61\%) had severe preeclampsia, 9(5.84\%) had eclampsia. $154(100 \%)$ of the patients had pedal edema followed by $93(60 \%)$ of the patients had hemodilution, $61(40 \%)$ of patients had blurring of the vision as initial symptom.

Retinal changes were seen in $42(27.27 \%)$ patients. The association with retinal changes and different parameters are shown in Table 2. Two patients had retinal detachment. Two patients with vision of CF $2 \mathrm{mts}$ in both eyes, 1 patient regained her vision till $6 / 9$ by the end of 1week. $2^{\text {nd }}$ patient gained vision $6 / 12$ in one eye and $6 / 36$ partial in the other eye.

Table 1: Showing no of patient who have retinopathy changes $(n=154)$.

\begin{tabular}{|c|c|c|}
\hline $\begin{array}{c}\text { Grading of } \\
\text { Retinopathy }\end{array}$ & $\begin{array}{c}\text { Patient with } \\
\text { changes }\end{array}$ & $\%$ \\
\hline No changes & 112 & $72.72 \%$ \\
\hline Grade I & 19 & $12.33 \%$ \\
\hline Grade II & 19 & $12.33 \%$ \\
\hline Grade III & 0 & $0 \%$ \\
\hline Grade IV & 2 & $1.29 \%$ \\
\hline $\begin{array}{c}\text { Retinal } \\
\text { Detachment }\end{array}$ & 2 & $1.29 \%$ \\
\hline
\end{tabular}

\section{DISCUSSION}

Pregnancy induced hypertension is responsible for maternal mortality in developing countries [5]. Visual symptoms are reported in $25 \%$ of eclampsia, $50 \%$ of preeclampsia of PIH. In early studies of preeclampsia the incidence of foveal retinal arteriolar abnormalities was reported to be $30-100 \%$ [3]. The other changes of HTN retinopathy are retinal edema, hemorrhages, exudates, cotton wool spots, papillophlebitis, elsching spots, macular edema, RPE lesions, serous retinal detachment [6], retinal artery and 
Table 2: Showing association of retinopathy with different variables of PIH ( $n=154)$.

\begin{tabular}{|c|c|c|c|c|c|c|c|}
\hline \multirow{2}{*}{ Parameter } & \multicolumn{5}{|c|}{ Retinal changes } & \multirow{2}{*}{ total } & \multirow{2}{*}{ Pvalue } \\
\hline & Nil=112 & $\mathrm{Gr} \mathrm{l}=19$ & Gr II=19 & Gr IV=2 & $\mathrm{RD}=2$ & & \\
\hline \multicolumn{8}{|c|}{ Blood pressure } \\
\hline $450 / 100 \mathrm{~mm} \mathrm{Hg}$ & 84 & 10 & 4 & 0 & 0 & 97 & \\
\hline$>150 / 100 \mathrm{~mm} \mathrm{Hg}$ & 28 & 9 & 16 & 2 & 2 & 57 & 0.0001 \\
\hline \multicolumn{8}{|c|}{ Proteinuria } \\
\hline $\mathrm{Nil}$ & 85 & 6 & 4 & 0 & 0 & 95 & \\
\hline+ & 26 & 3 & 2 & 0 & 0 & 31 & \\
\hline H & 1 & 10 & 7 & 0 & 0 & 18 & \\
\hline$+1+$ & 0 & 0 & 6 & 1 & 1 & 8 & \\
\hline H+H & 0 & 0 & 0 & 1 & 1 & 2 & 0.0001 \\
\hline \multicolumn{8}{|c|}{ Severity of disease } \\
\hline \begin{tabular}{c|} 
Mild \\
preedampsia \\
\end{tabular} & 71 & 6 & 7 & 0 & 0 & 84 & \\
\hline $\begin{array}{c}\text { Sever } \\
\text { preedampsia }\end{array}$ & 41 & 10 & 10 & 0 & 0 & 61 & \\
\hline Edampsia & 0 & 3 & 2 & 2 & 2 & 9 & 0.0001 \\
\hline \multicolumn{8}{|c|}{ Age } \\
\hline $18-24$ & 67 & 11 & 17 & 1 & 1 & 97 & \\
\hline $25-31$ & 40 & 8 & 2 & 1 & 1 & 52 & \\
\hline $32-38$ & 5 & 0 & 0 & 0 & 0 & 5 & 0.412 \\
\hline \multicolumn{8}{|c|}{ Gestational age } \\
\hline $20-28$ & 8 & 2 & 3 & 0 & 0 & 13 & \\
\hline $29-32$ & 24 & 4 & 5 & 1 & 0 & 34 & \\
\hline 32 onwards & 80 & 13 & 11 & 1 & 2 & 107 & 0.856 \\
\hline \multicolumn{8}{|c|}{ Gravida } \\
\hline Primi & 53 & 17 & 12 & 2 & 1 & 85 & \\
\hline Multi & 46 & 0 & 0 & 0 & 1 & 47 & \\
\hline Grand multi & 13 & 2 & 7 & 0 & 0 & 22 & 0.0001 \\
\hline \multicolumn{8}{|c|}{ Blood urea } \\
\hline$=<40 \mathrm{mg} / \mathrm{dl}$ & 107 & 16 & 18 & 2 & 2 & 145 & 5 \\
\hline$\lambda 40 \mathrm{mg} / \mathrm{dl}$ & 6 & 3 & 1 & 0 & 0 & 9 & 0.507 \\
\hline \multicolumn{8}{|c|}{ Serum creatinine } \\
\hline$=<1.2 \mathrm{mg} / \mathrm{dl}$ & 96 & 16 & 17 & 2 & 1 & 132 & 工 \\
\hline$>1.2 \mathrm{mg} / \mathrm{dl}$ & 16 & 3 & 2 & 0 & 1 & 22 & 0.614 \\
\hline \multicolumn{8}{|c|}{$\mathrm{A} / \mathrm{G}$ ratio } \\
\hline$=4.7$ & 112 & 18 & 18 & 2 & 2 & 152 & res \\
\hline$>1.7$ & 0 & 1 & 1 & 0 & 0 & 2 & 0.186 \\
\hline
\end{tabular}

vein occlusion, optic neuritis, optic atrophy and isolated cases of acute ischemic optic neuropathy [7], Bilateral exudative Retinal detachment, transient blindness [8,9], cortical blindness [10-12] seen in severe Pregnancy ind-uced hypertension. Tadin et al [13] a study of 40 women with preeclampsia, $45 \%$ showed abn-ormalities.The average age of 40 patients was 29.1 years. In another study by Jaffe and Schatz, mean age of the patient was 28 years [14]. Preeclampsia a disease of $1^{\text {st }}$ pregnancy $16-25 \%$ and $12-15 \%$ of subsequent pregnancies [15].

In our study of 85 patients $55.19 \%$ were primigravida with $\mathrm{PIH}$ had retinal involvement $32(37 \%)$ that correlating with $30-100 \%$ [3]. M ost common ocular finding is severe arteriolar spa-sm [3], evidenced by either segmental or gene-ralized constriction of retinal arterioles (Wagner represented spastic lesion of retinal arteriole in $70 \%$ of $\mathrm{PIH}$ ) [18]. The prevalence of HTN retinopathy[15] changes 42(27.27\%) in our study showed significant association with severity of preeclampsia $(p=0.0001)$ similar to Reddy et al [16].

Landismer $\mathrm{R}$ et al have found correlation between degree of retinopathy and severity of preeclampsia Tadin et al found a statistical correlation between proteinuria, BP, HTN retinopathy [13]. The degree of retinopathy was directly proportional to severity of pre eclampsia. Amongst 154patients, proteinuria ranged from 1+ to 4+ which correlates with Tadin et al [13] we have seen exudative retinal detachment in eclampsia patient with HELLP syndrome. Saito and Tano reported $43 \%$ with retinal and choroidal changes in a series of $41 \%$ pre-eclamptic and eclamptic patients [17]. Exudative retinal detachment tends to be bilateral, diagnosed post partum, more frequent in primiparous women and tends to resolve completely post partum [18]. We came across 1 patient who complained of cortical blindness, in immediate post partum 1 day, which resolved within 5 hours. Cortical blindness, which affects up to $15 \%$ of preeclamptic and eclamptic women, is often preceded on accompanied with headaches, hyperreflexia and paresis. An MRI may show focal occipital lobe edema, including bilateral edema of LGB retinopathy hypertensive lesion on T2 weighed image. The constellation of findings (headache, seizures, cortical blindness and altered mental state) associated with preeclampsia, eclampsia and other diseases is referred to as reversible posterior leukoencephalopathy syndrome.

\section{CONCLUSIONS}

Retinal changes were seen in $42(27.27 \%)$ of patients with PIH and they were significantly associated with blood pressure, proteinuria and severity of PIH. But with blood urea and serum creatinine, serum $A / G$ we did not find any significant correlation. Retinal changes were observed more in the primi gravida PIH patients compared to multi gravida.

\section{ACKNOWLEGEM ENT}

We thank Dr. Rama Devi, Professor and HOD, Department of Ophthalmology, Chalmeda Anand Rao Institute of Medical Sciences, and the faculty, patients and all those who helped us to complete the study. 


\section{REFERENCES}

[1]. Lowe SA, Brown M A, Dekker GA, Gatt S, M cLintock $C K, M C M$ ahon LP, et al. guidelines for the management of hypertensive disorders of pregnancy 2008. Aust N Z J Obstet Gynaecol. 2009;49:242-246.

[2]. Nelson-Piercy C. Handbook of Obstetric M edicine. $3^{\text {rd }}$ ed: Informa Health Care; 2007.

[3]. Richard RO. Pregnancy induced hypertension (preeclampsia- eclampsia), In: SehachalAP ,M urphyRB (eds), Retina 2nd ed, St. Louis M osby; 1944:1405-1412.

[4]. Kanski JJ. 2nd ed. Oxford: Butterworth Heinmann; 1989. Clinical ophthalmology-a systematic approach; p. 329.

[5]. NG Kok Ying. Report on the confidential enquiry into maternal deaths in Malaysia 1997-2000, by division of family health department, Ministry of Health Malaysia, Putrajaya. 2005:30-31.

[6]. Dornan KJ, Mallek DR, Wittmann BK. The sequelae of serous retinal detachment in preeclampsia.Obstetrics and Gynaecology. 1982;60:657-663. [PubMed]

[7]. Beck R, Gamel JW, Willcourt RJ, Berman G. Acute ischemic optic neuropathy in severe preeclampsia. Am J Ophthalmol. 1980;90:342-346. [PubM ed]

[8]. Nalliah S, Thavarasha AS. Transient blindness in pregnancy induced hypertension. Int J Gynaecol Obstet. 1989;29:249-251. [PubM ed]

[9]. Achanna S, Monga D, Sivagnanam Transient blindness in pregnancy induced hypertension. Asia Oceania J Obstet Gynaecol. 1994;20:49-52. [PubMed]
[10]. Grimes DA, Ekbladh LE, M cCartney WH. Cortical blindness in preeclampsia. Int J Gynaecol Obstet. 1980;17:601-603. [PubM ed]

[11]. Liebowitz HA, Hall PE. Cortical blindness as a complication of eclampsia. Ann Emerg Med. 1984;13:365-367. [PubM ed]

[12]. Apollon KM, Robinson JN, Schwartz RB, Norwitz ER. Cortical blindness in severe preeclampsia: computed tomography, magnetic resonance imaging, and sigle-photon-emission tomography findings. Obstet Gynaecol. 2000;95:1017-1019. [PubMed]

[13]. Tadin I, Bojiæ L, M imica M , Kareloviæ D, Dogas Z. Hypertensive retinopathy and preeclampsia. CollAntropol. 2001;25:77-81. [PubM ed]

[14].Jaffe G, Schatz H. ocular manifestations of preeclampsia. Am J Ophthalmol. 1987;103:309315. [PubM ed]

[15]. Karki P, Malla KP, Das H, Uprety DK. Association between pregnancy induced hypertensive fundus changes and fetal outcome. Nepal J Ophthalmol. 2010;2:26-30. [PubM ed].

[16]. Reddy SC. Ocular fundus changes in toxemia of pregnancy. The Antiseptic. 1989;86:367-372.

[17]. Saito Y, Tano Y. Retinal pigment epithelial lesions associated with choroidal ischemia in preeclampsia. Retina. 1998;18:103-108. [PubM ed]

[18]. Wagner HP. Lesions of the optic nerve and retina in pregnancy, JAM A 1934;103:1910-13.

How to cite this article:

Anil kumar Bhupally, Sindu Sulekha, Rama Devi E, Swathi M, Rohini M, Shruthi T. Prevalence of Hypertensive Retinopathy Changes in Pregnancy induced Hypertension. Int J Intg M ed Sci 2015;2(10):182-185. DOl: 10.16965/ ijims.2015.129 